\title{
PROGRAMMING EDUCATIONAL MOBILE APPLICATIONS IN APP INVENTOR AND ANDROID STUDIO
}

\author{
Patrik VOŠTINÁR*, Univerzita Mateja Bela, Slovenská republika
}

Přijato: 29. 5. 2017 / Akceptováno: 14. 7. 2017

Typ článku: Teoretická studie

DOI: $10.5507 /$ jtie.2017.015

Abstract: Currently, mobile devices are very popular among people of all ages. After tablets appeared on the market, mobile devices started to be widely used in firms, schools as well as in free time. Nowadays, mobile application stores offer a lot of applications. In these stores we can find also applications aimed to be used as supplements during educational process. Although, there is not enough of these applications. In this article, we focus on the creating new mobile applications which can be used in mathematical teaching. Two of these applications were created in Android Studio, three of them were created in App Inventor. This environment offers creating new mobile applications without previous knowledge about programming. In the article we focus also on the creating applications with the use of this environment.

Key words: mobile applications, m-learning, mathematics, geometric shapes.

\section{PROGRAMOVANIE MOBILNÝCH VZDELÁVACÍCH APLIKÁCIÍ V APP INVENTOR A ANDROID STUDIO}

Abstrakt: V súčasnosti sa mobilné zariadenia tešia vel'kej popularite u l’udí všetkých vekových kategórií. Príchodom mobilných zariadení typu tablet si mobilné zariadenia čoraz častejšie našli využitie vo firmách, v školstve, ako aj vo vol'nom čase. V súčasnosti obsahujú obchody s mobilnými aplikáciami vel'ké množstvo aplikácií. V týchto obchodoch nájdeme aj aplikácie určené ako podporný prostriedok vo vyučovacom procese. Takýchto aplikácií stále nie je vel'a. $V$ tomto príspevku sme sa zamerali na vytváranie mobilných aplikácií vo vyučovaní. Vytvorili sme pät' mobilných aplikácii určených na podporu vyučovania matematiky. Dve aplikácie boli vytvorené v prostredi Android Studio a tri aplikácie boli vytvorené v prostredí App Inventor. Toto prostredie umožňuje vytvárat' mobilné aplikácie bez predchádzajúcej potreby znalosti programovania. V príspevku sa venujeme tiež vytváraniu aplikácií v tomto prostredí.

Kl'účové slová: mobilné aplikácie, m-learning, matematika, geometrické tvary.

*Autor pro korešpondenciu: patrik.vostinar@umb.sk 


\section{1 Úvod}

Rozvoj výpočtovej techniky v posledných dvadsiatych rokoch ovplyvnil všetky odvetvia l'udskej činnosti. S rozvojom spoločnosti sa začali používat' vo vyučovaní rôzne didaktické pomôcky. Medzi najvýznamnejšie pomôcky, ktoré najviac ovplyvnili vzdelávanie zarad’ujeme začlenenie informačno-komunikačných technológií do vzdelávania.

Výskumy u nás a vo svete dokazujú, že použivanie týchto pomôcok zvyšuje názornost' a efektivitu vo výučbe. Warschauer (2006) vo svojich štúdiách uvádza, že študenti učením prostredníctvom mobilných zariadení získali široké zručnosti, vedomosti a schopnosti, ktoré podporili vzdelávanie a gramotnost' študentov. Drigas a Pappas (2016) uviedli, že vzdelávanie online a pomocou mobilných zariadení bolo pre študentov motivujúcejšie a matematické kurzy boli pre nich viac prít’ǎlivejšie ako klasické vyučovanie. Bayerl a Žilková (2017) vo svojich výskumoch uviedli, že používanie iBooks učebníc na tabletoch nie je iba alternatíva $\mathrm{k}$ tradičnej forme vyučovania, ale v niektorých ohl'adoch prekročilo ich očakávania. Pokorný (2013) vo svojom výskume, ktorý realizoval na vzorke 172 študentov v rokoch 2010-2013 dokázal, že študenti, ktorí riešili matematické problémy s použitím interaktívnych prvkov boli úspešnejší ako študenti, ktorí pri riešení nepoužívali interaktívne prvky. Aj vzhl'adom na tieto pozitívne výsledky výskumov prebehlo na Slovensku viacero programov $\mathrm{s}$ ciel'om zavádzania najmodernejších informačno-komunikačných technológií do vzdelávania. Vd’aka tomu disponuje na Slovensku takmer každá škola aspoň jednou interaktívnou tabul'ou, počítačovou miestnost'ou a v posledných rokoch aj tabletovou miestnost'ou. Učitelia na všetkých typoch škôl majú k dispozícií viacero elektronických výučbových materiálov, ktoré sú určené primárne pre počítače.

V súčasnosti na slovenských školách postupne pribúdajú tabletové miestnosti. Najväčší problém však vidíme v tom, že učitelia nevedia, čo majú s týmito zariadeniami robit'. Výučbových materiálov určených pre tieto zariadenia je nedostatok. Materiály postupne pribúdajú, ale pomalým tempom. Medzi najznámejší projekt zavádzania tabletov do škôl na Slovensku zarad'ujeme projekt „Škola na dotyk“. Zapojením do tohto projektu získali školy školenia na výučbu pomocou tabletov a dostali tiež zoznam odporúčaných mobilných aplikácií vhodných na výučbu. Najväčší problém zavádzania výučby pomocou mobilných zariadení je nedostatok výučbových aplikácií.

Z tohto dôvodu sme sa rozhodli vytvorit' mobilné vzdelávacie aplikácie vhodné pre vyučovanie matematiky na základných školách. Vytvorili sme pät' aplikácií, ktoré môžu slúžit' ako podporný materiál pre vyučovanie matematiky. Aplikácie v žiadnom prípade nenahrádzajú vyučovací proces, iba ho doplńajú. Aplikácie poskytujú neobmedzené množstvo vygenerovaných príkladov, ktoré musí žiak vyriešit' a aplikácia následne vyhodnotí správnost' riešenia. Aplikácie umožňujú aj skontrolovanie výsledku l’ubovol'ného príkladu na danú tému - žiak vloží do aplikácie zadanie a aplikácia následne vypíše rovno výsledok, bez možnosti ukázania riešenia. Táto funkcionalita môže byt' pre niekoho výhodou alebo aj nevýhodou. Hlavnou výhodou je, že používanie týchto aplikácií nemá zmysel pri písomkách a súčasne kritici digitálneho vzdelávania sa nemôžu opierat' o výskumy, napr. že používaním digitálnych médií vytvárame u mladých l’udí digitálnu demenciu. Na základe štúdie neurovedca Spiztera (2014) „u detí a mladistvých klesá vinou digitálnych médií schopnost' učenia sa a výsledkom sú poruchy pozornosti a čítania“. Z tohto dôvodu naše aplikácie je možné používat' iba na generovanie úloh a následnú kontrolu výsledku, v prípade funkcionality Zistenie výsledku iba vypísanie výsledku, nie jeho riešenia. 
Existuje viacero programovacích jazykov a nástrojov, v ktorých je možné vytvárat' mobilné aplikácie. V prípade, že chceme vytvorit' mobilnú aplikáciu, väčšinou potrebujeme mat' aspoň základné znalosti programovania. Výnimkou je nástroj App Inventor, ktorý umožňuje vytvárat' mobilné aplikácie bez predchádzajúcej znalosti programovania, nie však logického zmýšl’ania. Práca v tomto nástroji je vel'mi jednoduchá a po absolvovaní úvodných tutoriálov by mal byt' každý schopný vytvorit' mobilnú aplikáciu pre operačný systém Android. App Inventor je vel'mi podobný programovaciemu jazyku Scratch, s ktorým sa stretávajú už žiaci na základných školách. Z tohto dôvodu je nástroj App Inventor vhodný aj na výučbu programovania. Vd’aka tomuto nástroju si môžu študenti už na základných školách vytvorit’ svoju aplikáciu, resp. hru, ktorú si môžu nahrat' do svojho mobilného telefónu. V tomto nástroji sme vytvorili ako ukážku použitia tri mobilné matematické aplikácie. Zvyšné dve aplikácie sme vytvorili v nástroji Android Studio, ktoré vyžaduje znalosti programovania v programovacom jazyku Java.

\section{M-learning}

Medzi najnovšími trendami vo vzdelávaní je možné pozorovat' trend rastúceho používania mobilných zariadení vo vyučovaní. $\mathrm{V}$ prípade používania mobilných technológií vo vyučovaní hovoríme o tzv. m-learningu. Podobne ako e-learning, aj tento pojem má viacero definícií.

M-learning je taká forma výučby, pri ktorej sa využívajú mobilné zariadenia. V širšom zmysle môžeme za takéto zariadenia považovat' mobilné telefóny, smartfóny, notebooky a tablety (Koreňová, 2015).

Mobilné zariadenia je možné využit' pri správe študijného systému. Pomocou aplikácií v mobilných zariadeniach je možné študentom distribuovat' študijné materiály, informovat' študentov o termínoch skúšok a prednášok, ako i o novinkách na ich škole (Nocar \& Zdráhal, 2015).

\section{Projekty zamerané na m-learning}

V posledných rokoch sa používanie tabletov rozšírilo a vd’aka vel'kej konkurencií na trhu sú tablety dostupné pre každého. Existuje viacero projektov, ktoré zavádzajú tablety do škôl.

Jedným z prvých projektov zavádzania tabletov do škôl na Slovensku bol projekt Škola na dotyk, ktorý sa realizoval v rokoch 2013-2015. Za týmto projektom stálo vzdelávacie centrum Edulab (nezisková organizácia) s podporou spoločnosti Samsung. Vd’aka tomuto programu získalo pätnást' vybraných škôl na Slovensku viac ako štyristo tabletov vybavených dotykovou vrstvou, na ktorú sa dá písat' integrovaným perom.

Druhý program zaoberajúci sa vybavením digitálnych učební a digitálnym vzdelávacím obsahom na Slovensku má názov Digiškola. Tento projekt priniesol národný projekt Elektronizácia vzdelávacieho systému regionálneho školstva, realizovalo ho ministerstvo školstva, vedy, výskumu a športu Slovenskej republiky v spolupráci s Metodicko-pedagogickým centrom rokoch 2013-2015. Projekt bol financovaný $\mathrm{z}$ prostriedkov európskej únie $\mathrm{v}$ rámci operačného programu informatizácia spoločnosti (OPIS). V rámci tohto projektu získali materské, základné a stredné školy na Slovensku moderné digitálne vybavenie (20 000 notebookov sa rozdelilo medzi 1026 škôl). Počas tohto projektu mohla každá škola získat' program Samsung School, ktorý zabezpečuje manažment tabletovej učebne. 


\section{Programovanie vzdelávacích aplikácií}

V súčasnosti existuje na trhu viacero mobilných operačných systémov. Medzi najpoužívanejšie mobilné operačné systémy patrí Android od firmy Google a iOS od firmy Apple. Okrem týchto dvoch operačných systémov existujú ešte d'alšie operačné systémy pre mobilné zariadenia, ktoré však nedosahujú významný podiel na trhu a preto sme ich pri vytváraní vzdelávacích mobilných aplikácií nebrali do úvahy.

Na základe výskumov medzinárodnej analytickej firmy IDC z roku 2016 používalo celosvetovo mobilný operačný systém Android 79,6 \% mobilných zariadení. Operačný systém iOS používalo 18,7 \% mobilných zariadení. Aj ked' viaceré výskumy ukazujú rôzne štatistiky používania operačných systémov v mobilných zariadeniach, všetky sa zhodujú na tom, že operačný systém Android výrazne dominuje na celosvetovom trhu s mobilnými zariadeniami. Slovensko nie je výnimkou, operačný systém Android používa väčšina mobilných zariadení zakúpených na Slovensku. Školy na Slovensku, ktoré disponujú tabletovou učebňou používajú väčšinou tiež operačný systém Android. Z tohto dôvodu sme sa rozhodli vytvárat' aplikácie zatial' iba pre operačný systém Android.

\section{Programovacie prostredie}

Odporúčaný nástroj na vytváranie mobilných aplikácií pre Android je nástroj Android Studio. Aplikácie sa v tomto nástroji píšu v programovacom jazyku Java spolu s vývojovou sadou Android SDK (software development kit). Nástroj spolu s vývojovou sadou je bezplatný a dostupný na oficiálnej stránke systému Android. Väčšina mobilných aplikácií je vytvorená práve v tomto nástroji. Mobilné aplikácie je však možné vytvárat' aj v d’alších jazykoch a nástrojoch. Jednými z možných programovacích jazykov sú jazyky $\mathrm{C}$ a $\mathrm{C}++$ s použitím vývojovej sady Android Native Development Kit (NDK). Ďalšou možnost'ou je vytvorenie webovej mobilnej aplikácie, ktorú je možné spustit' na l'ubovol'nom mobilnom operačnom systéme. Na vytváranie takýchto aplikácií sa najčastejšie používajú jazyky HTML5, nástroj PhoneGap a Titanium Mobile Development.

\section{Android Studio}

Nástroj Android Studio je oficiálne prostredie určené pre vytváranie mobilných aplikácií pre operačný systém Android. Prostredie je multiplatformové, teda je možné ho stiahnut' pre operačné systémy Windows, Mac OS a Linux. Po nainštalovaní môžeme vytvárat' aplikácie a následne ich testovat' $\mathrm{v}$ reálnych mobilných zariadeniach alebo na emulátore, ktorý simuluje prostredie Androidu v programe Android Studio. Na vytváranie aplikácií však musíme vediet' aspoň základy objektovo orientovaného programovacieho jazyka Java, ktorý patrí medzi najrozšírenejšie programovacie jazyky v súčasnosti. Vzhl'ad obrazoviek vytvárame v značkovacom jazyku XML, ktorý nám umožňuje vytvárat' štruktúrované dokumenty vel'mi flexibilným spôsobom.

\section{App Inventor}

App Inventor je programovacie prostredie na tvorbu mobilných aplikácií pre mobilné zariadenia s operačným systémom Android. Na vytváranie aplikácií musíme byt' pripojení na internet, nakol'ko toto prostredie sa nachádza $\mathrm{v}$ cloude - nevyžaduje teda žiadnu inštaláciu. Na vytváranie aplikácií je potrebné sa prihlásit' na stránke http://appinventor.mit.edu. Výhodou tohto prostredia je to, že ho vývojári poskytli používatel'om zadarmo. Vytvorila ho spoločnost' Google spolu s MIT (Massachusetts 
Institute of Technology). Prostredie je vel'mi podobné programovaniu v aplikácií Scratch, s ktorým sa žiaci stretávajú už na základných školách.

V roku 2015 používalo App Inventor tri milióny používatel’ov v 195 krajinách. Pomocou App Inventoru môžu učitelia na všetkých stupňoch škôl učit' deti lepšie pochopit' učivo tak, že si k danej téme vytvoria vlastnú aplikáciu, na ktorej si konkrétnu problematiku lepšie precvičia. Pomocou App Inventoru si učitelia môžu vytvorit’ vlastné aplikácie, ktoré budú používat' na svojich hodinách a tým pádom zvýšia motiváciu žiakov. App Inventor sa môže použit' aj na precvičovanie algoritmického myslenia a na vyučovanie programovania na všetkých typoch škôl. App Inventor má vel’a vlastností, ktoré podporujú žiakov pri vyučovaní základov programovania a sú nápomocné pri získavaní praktických skúseností s tvorbou mobilných aplikácií. Žiaci majú možnost' na hodinách informatiky navrhnút' a $\mathrm{v}$ pomerne krátkom čase vytvorit' funkčnú aplikáciu/hru pre mobilné zariadenia, čo je v súčasnosti vel’mi populárne medzi mladými l'ud'mi. Oproti programovaniu mobilných aplikácií v jazyku Java má možnost' každý si vytvorit' rýchlo, bez znalostí pokročilých vedomostí programovania svoju mobilnú aplikáciu. App Inventor je teda vhodný pre všetkých začiatočníkov v programovaní bez ohladu na ich vek.

\section{Postup vývoja aplikácií}

Pre vytváranie aplikácií sa musíme prihlásit pomocou účtu v e-mailovej službe Gmail. Po úspešnom prihlásení sa zobrazí hlavná stránka nástroja App Inventor, v ktorej môžeme vytvárat' a vymazávat' projekty. Na tejto stránke sa teda nachádzajú všetky vytvorené projekty prihláseného používatel'a. Všetky projekty sa ukladajú na server, ale používatelia si ich môžu samozrejme stiahnut' -zálohovat' do svojich počítačov. Vytvorené projekty je možné zdiel'at's ostatnými členmi App Inventor komunity. Zdiel'ané projekty môžu ostatní členovia komunity stiahnut' medzi svoje projekty a následne sa inšpirovat', ohodnotit', poprípade ich rozšrírit.

\section{Architektúra aplikácií}

App Inventor podporuje komponentové a udalost'ami riadené programovanie. Vývojár najskôr zostaví použivatel'ské rozhranie (ako bude aplikácia vyzerat') - vyberie vizuálne komponenty a nastaví ich vlastnosti. Následne je potrebné naprogramovat' reakcie na udalosti. Udalosti sa vytvárajú pomocou blokov, ktoré sa do seba poskladajú (Lovászová a kol., 2016).

App Inventor obsahuje dostatočné množstvo komponentov, ktoré môžeme použit' v našich aplikáciách. Použit' môžeme základné komponenty (tlačidlo, zaškrtávacie tlačidlo, obrázok, list, posuvník, prepínacie tlačidlá, výber z dátumu a času, atd’.). Do aplikácie môžeme vkladat' multimediálne prvky (video, zvuk), ukladat údaje do databázy, reagovat' na výstupy zo senzorov (gyroskop), prepojit' aplikáciu so sociálnymi sietami. V prípade mobilného zariadenia, ktoré podporuje vloženie sim karty (obsahuje 3G modul), môžeme vytvorit' aplikáciu, ktorá bude pristupovat' ku kontaktom, správam a umožní telefonovanie. V súčasnosti sú viaceré školy zapojené do sútaží s LEGO robotom, vývojári App Inventoru pridali aj komponentu na ovládanie takýchto robotov. 


\section{Dizajnér komponentov (Designer)}

Dizajnér komponentov sa skladá z viacerých častí: zoznam všetkým komponentov (Palette), prehliadač (Viewer), zoznam komponentov, ktoré sú použité v obrazovke (Components) a nastavenia komponentu. Ukážku dizajnéra je možné vidiet' na obrázku 1.

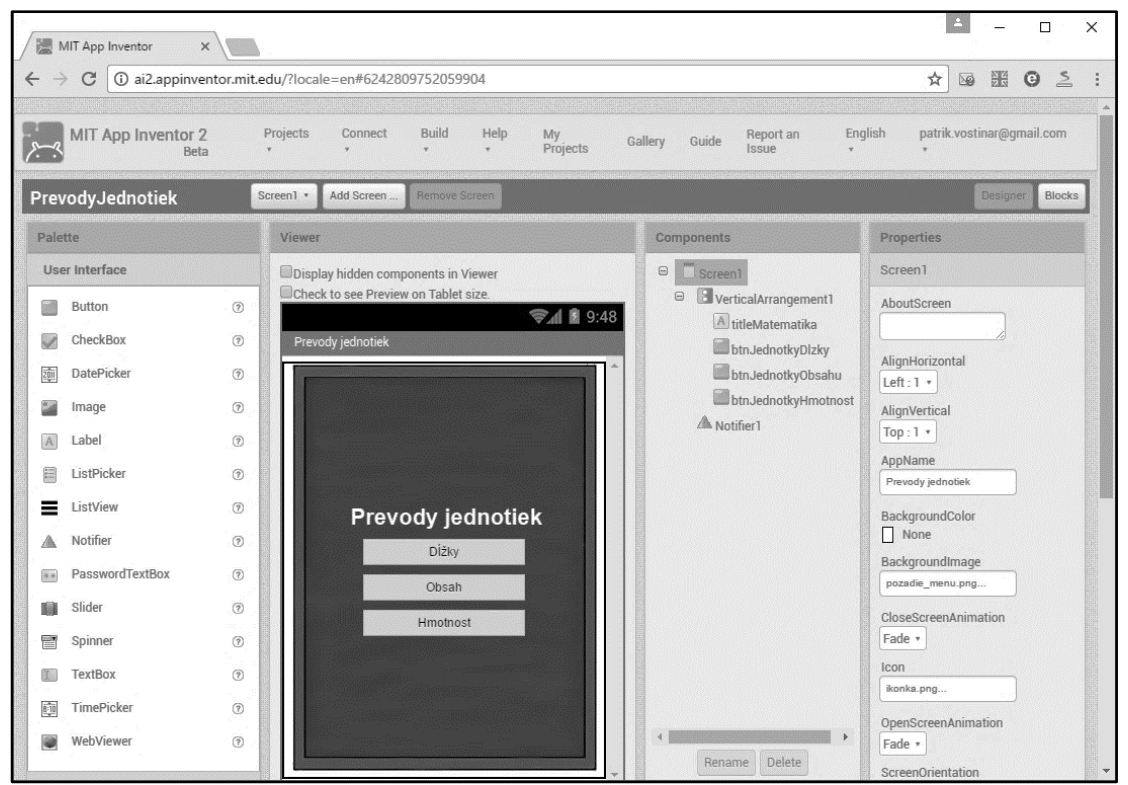

Obr. č. 1: Prostredie App Inventor - čast' dizajnér (zdroj: vlastný).

Prehliadač (Viewer) predstavuje okno obrazovky mobilného zariadenia. Komponenty (User Interface) presúvame $\mathrm{z}$ palety nástrojov pomocou myšky do časti prehliadač (Viewer). V časti zoznam všetkých komponentov (Components) sú hierarchicky umiestnené všetky komponenty, ktoré $\mathrm{v}$ aplikácií používame. V nastaveniach (Properties) nastavujeme vlastnosti pre každú komponentu.

Všetky komponenty majú svoje vlastnosti. Pomocou týchto vlastností môžeme nastavit' každej komponente iné začiatočné vlastnosti. S týmito vlastnost’ami môžeme pracovat' v časti editor blokov, kde napríklad nastavíme nejakú vlastnost', poprípade ju zmeníme.

\section{Editor blokov (Blocks editor)}

$\mathrm{V}$ tejto časti definujeme, ako bude aplikácia reagovat' na udalosti (napríklad stlačenie tlačidla). App Inventor poskytuje pre definovanie udalostí systém blokov, ktorý funguje na princípe udalost' - reakcia. Pre každú udalost', ktorá môže nastat' v aplikácií musíme vytvorit' samostatný blok kódu. Udalost' môže vyvolat' používatel' napríklad stlačením tlačidla. Udalost' sa môže vyvolat' aj po uplynutí nastaveného času, po prijatí SMS správy, atd’. Najčastejšie sa však vyvolá udalost' pri spustení obrazovky alebo aplikácie. 
Táto čast' sa skladá z častí blokov Blocks, a obdobne, ako pri dizajnéri komponentov, aj z prehliadača Viewer. V aplikácií môžeme použit' vel'ké množstvo blokov - napr. riadiace bloky (podmienky, cykly), logické operátory, premenné, procedúry, atd'.

Ukážka editora blokov, spolu s príkladom bloku kódu - funkcie, sa nachádza na obrázku 2.

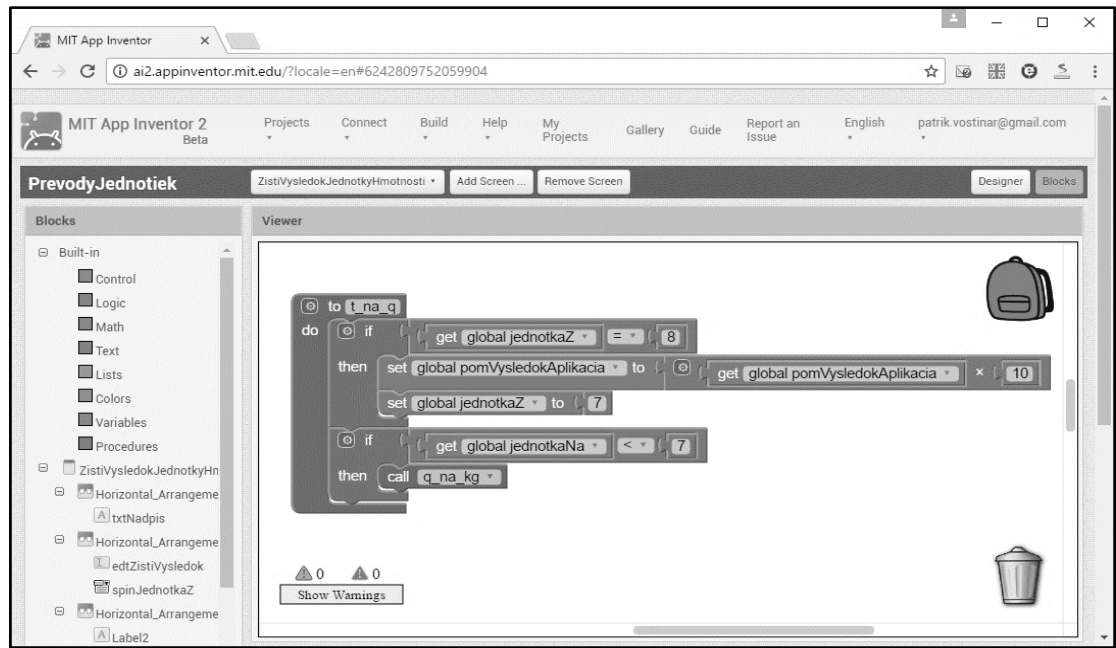

Obr. č. 2: Prostredie App Inventor - čast' bloky kódov (zdroj: vlastný).

\section{Využitie nástroja App Inventor vo vyučovaní programovania}

Tvorcovia nástroja App Inventor pri vytváraní tohto vývojového prostredia vychádzali z programovacieho jazyka Scratch, ktoré sa používa na vyučovanie programovania. $\mathrm{Z}$ tohto dôvodu by nemal byt' problém pre učitel'ov informatiky, ktorí predtým používali jazyk Scratch začat' využívat' App Inventor na vyučovanie programovania. Hlavnou výhodou App Inventoru oproti jazyku Scratch je vytváranie aplikácií pre mobilné zariadenia, ktoré sa v súčasnosti tešia vel'kej popularite nielen u školopovinných detí. $\mathrm{Z}$ tohto dôvodu sa autor aplikácií rozhodol v rámci svojho doplňujúceho vzdelávacieho štúdia vyskúšat' vyučovat' programovanie v tomto nástroji na základnej škole v Banskej Bystrici v akademickom roku 2014/2015. Praxujúci učitel' (autor aplikácií) vytvoril dve vzorové aplikácie - aplikáciu kocúr a krtko, ktoré žiaci následne programovali na štyroch vyučovacích hodinách. Nakol'ko žiaci mali skúsenosti s programovaním v jazyku Scratch, dostali stručný úvod do programovania v App Inventore. Po tomto úvode, dostali žiaci vytlačené obrazovky s popisom, ako a čo má aplikácia robit'. Pri každej obrazovke bol zoznam komponentov, ktoré majú použit' na danej obrazovke. Menšia polovica žiakov dokázala vytvorit' obidve aplikácie s minimálnym zásahom cvičného učitel'a. Zvyšná čast' potrebovala intenzívnejšiu spoluprácu s cvičným učitel’om. Táto situácia však nebola prekvapujúca, nakol'ko učitel' upozorňoval pred vyučovaním cvičného učitel'a na fakt, že väčšina žiakov nemá záujem o informatiku a určite budú potrebovat' pomoc pri vytváraní aplikácií. Po vyučovaní však učitel’ pri rozoberaní hodiny s cvičným učitel'om pozitívne hodnotil nástroj App Inventor a aj zanietenost' žiakov 
pri programovaní. Žiaci prejavili väčší záujem o vyučovanie programovania, nakol'ko mohli použivat' na hodine súčasne počítače a tablety, na ktorých si skúšali vytvorené aplikácie. Žiaci, ktorí mali pri sebe mobilné telefóny s operačným systémom Android si ešte na hodine nainštalovali vytvorené aplikácie do svojich zariadení.

\section{5 Štruktúra vytvorených aplikácií}

Všetky mobilné aplikácie, ktoré sme vytvorili sú bezplatné a dostupné v špecializovanom obchode $\mathrm{s}$ mobilnými aplikáciami Play Store, ktorý sa nachádza $v$ každom mobilnom telefóne a tablete s operačným systémom Android. Po spustení aplikácie Play Store je potrebné zadat' do vyhl'adávania názov niektorej $\mathrm{z}$ našich vzdelávacích aplikácií (Zlomky, Geometrické tvary, Matematika, Rímske čísla, Prevody jednotiek) a následne si vybrat’ aplikáciu zo zoznamu ponúknutých aplikácii.

Po spustení každej zobrazí úvodné hlavné menu, kde si môže použivatel' vybrat', aký celok chce precvičovat'. Následne sa používatelovi zobrazia d'alšie možnosti Pomocník, Otestuj sa, Zistenie výsledku. Každá z ponúknutých možností má svoju funkciu. Grafika a funkcionalita všetkých nami vytvorených aplikácií je pri všetkých mobilných aplikáciách rovnaká.

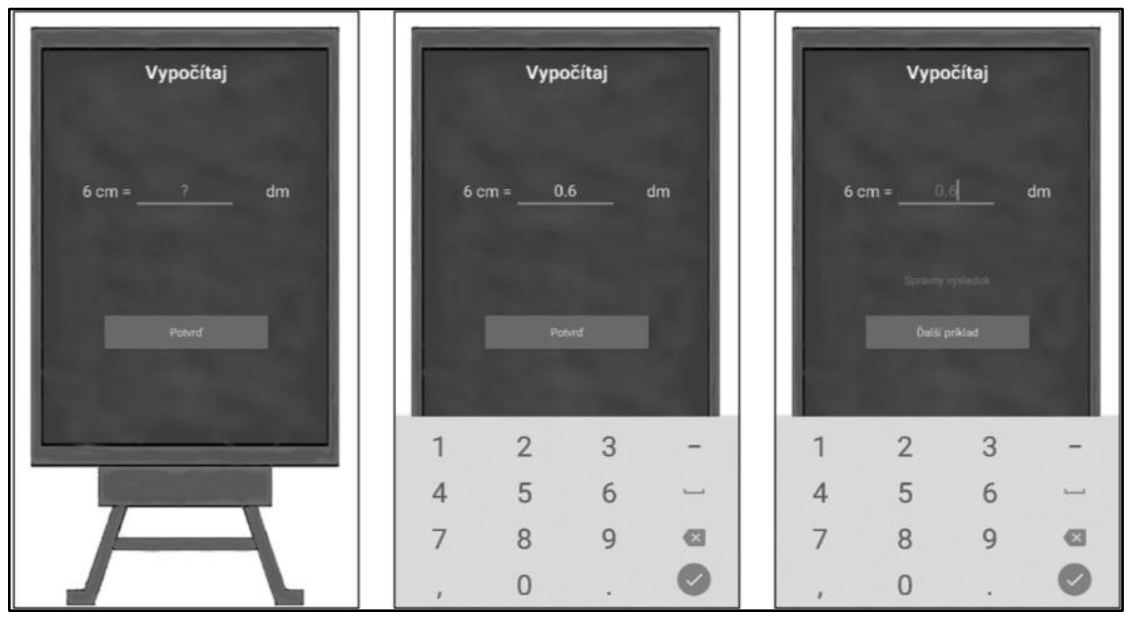

Obr.č. 3: Ukážka náhodného generovania úlohy (zdroj: vlastný).

Pomocník ponúka krátku teóriu spojenú so vzorovým riešením príkladu. Čast' Otestuj $s a$ umožňuje používatel'ovi precvičit úlohy z daného tematického celku. Používatel' si najprv musí vybrat' úroveň náročnosti riešenia úlohy, ktorá sa zobrazí v dialógovom okne. Pri väčšine úloh je možné vybrat' si z dvoch úrovní - z l'ahkej a z t’ažkej. Po zvolení náročnosti, aplikácia vygeneruje úlohu, ktorú používatel’ následne rieši. Na obrázku 3 si používatel' vybral preopakovanie celku prevody jednotiek dížky. Aplikácia v tomto prípade musí vygenerovat' zadanie, ktoré sa bude skladat' z čísla a z jednotky, ktoré sa má prevádzat'. V tomto prípade aplikácia musí ešte vygenerovat' náhodne jednotku, na ktorú sa bude prevádzat' číslo. 
Po vložení výsledku do príslušného pol’a v aplikácii (na miesto otázniku) je potrebné stlačit' tlačidlo Potvrd', po ktorom aplikácia vyhodnotí, či je dané riešenie správne alebo nesprávne. $V$ prípade, že výsledok nie je správny, používatel' je nútený opakovane riešit' úlohu (respektíve použije hardwarové tlačidlo telefónu - spät' a vráti sa do predchádzajúceho menu). $V$ prípade, že výsledok je správny, používatel' má na výber počítat' d'alší príklad, alebo sa môže vrátit' spät' do hlavného menu.

Na obrázku 4 je ukážka časti Zistenie výsledku, ktorá umožňuje používatel'ovi vložit' zadanie, ktoré aplikácia následne vyrieši.

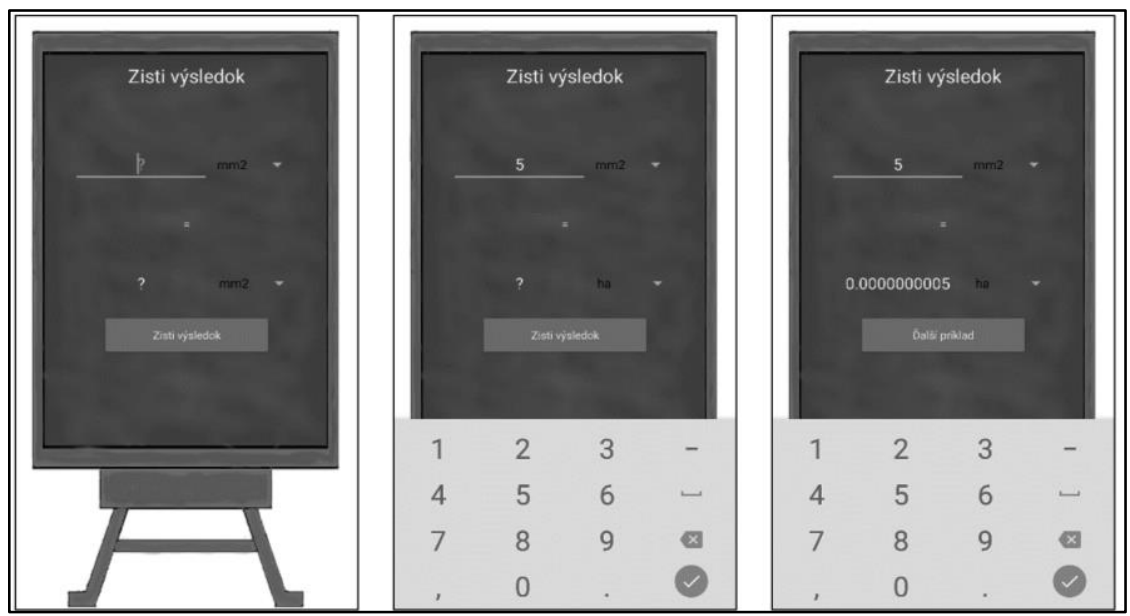

Obr. č. 4: Ukážka časti Zisti výsledok (zdroj: vlastný).

Túto funkcionalitu môžu využit hlavne rodičia, pri kontrole domácich úloh. Pri spustení tejto možnosti musí používatel' vložit' do aplikácie hodnotu, ktorú chce prevádzat' namiesto otáznika a tiež jednotky miery. Po stlačení tlačidla Zisti výsledok, aplikácia vypíše výsledok a následne má používatel' na výber, či si chce overit' alebo zistit' d’alší príklad alebo sa vráti spät' do hlavného menu aplikácie.

Všetky aplikácie poskytujú okamžitú spätnú väzbu a majú verifikačnú funkciu pre študenta. Aplikácie nenahrádzajú vyučovací proces, ale slúžia ako podporný materiál pre výučbu (Bayerl, Mojšová, Voštinár, 2015).

\section{Aplikácia Zlomky}

Táto aplikácia je zameraná na tematický celok zlomky. Primárne je určená pre žiakov a učitel’ov základných škôl, ale môže si ju do svojho mobilného zariadenia stiahnut' ktokolvvek. Aplikácia je dostupná $\mathrm{v}$ troch jazykoch - slovenčina, čeština a angličtina. Jazyk sa zobrazí podla toho, aký jazyk je prednastavený v mobilnom zariadení. V prípade prvotného nastavenia iného jazyka, ako je slovenčina resp. čeština, je aplikácia zobrazená $\mathrm{v}$ angličtine.

Požívatel' má na výber precvičenie nasledujúcich operácií:

- Zjednoduš a rozšír zlomky - úlohy na zjednodušovanie a rozširovanie zlomkov,

- Sčítaj a odčítaj zlomky - sčitovanie a odčitovanie zlomkov, 
- Násob a del' zlomky - násobenie a delenie zlomkov,

- Ktorý zlomok je väčší - porovnávanie zlomkov (väčší, menší alebo rovný),

- Zmiešané čísla - prevod zmiešaného čísla na zlomok a naopak,

- Zlomok a desatinné číslo - prevod zlomku na desatinné číslo a naopak.

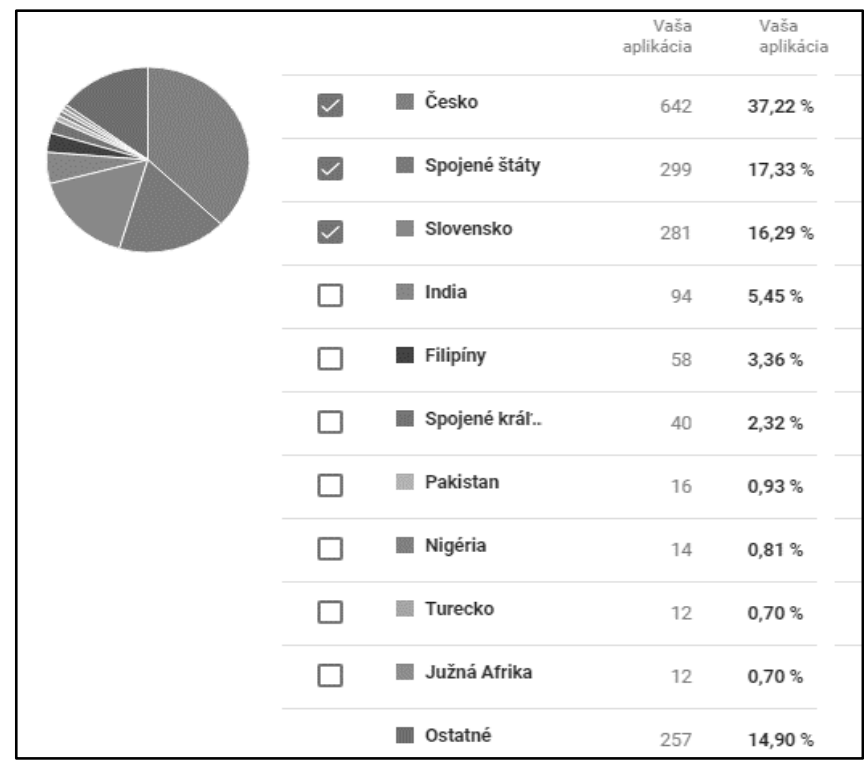

Obr. č. 5: Štatistické údaje o počte stiahnutí - aplikácia Zlomky (zdroj: vlastný).

Aplikácia Zlomky bola zverejnená v obchode Google Play dňa 9.3.2015. Od tohto dátumu aplikáciu stiahlo 1725 jedinečných používatel'ov. Aktívne ju má nainštalovanú v jednom, alebo vo viacerých zariadeniach, 508 používatel'ov (aplikáciu majú nainštalovanú a zariadenie bolo online za posledných 30 dní).

Nevieme však presne určit', na kol'kých zariadeniach bola, alebo je, aplikácia nainštalovaná. Správcovia počítačov na školách zvyčajne používajú jedno konto na viacerých tabletoch, aby mohli využit' výhodu operačného systému Android - stačí pridat' aplikáciu do jedného konta a aplikácia sa nainštaluje na všetky zariadenia s týmto kontom.

Vývojársky účet v obchode Play Store nám poskytuje základné štatistické informácie o počte stiahnutí vloženej aplikácie. Na obrázku 5 je zobrazený graf, ktorý ukazuje počet inštalácií aplikácie podl’a krajiny, kde sa nachádza. Z grafu vyplýva, že túto aplikáciu st'ahovali používatelia z celého sveta. Najviac používatel’ov stiahlo aplikáciu z Českej republiky. Vývojársky účet d'alej poskytuje informácie o počte stiahnutí aplikácie podl'a typu zariadenia - či je obrazovka väčšia ako 7 palcov. Túto aplikáciu stiahlo do zariadenia s vel'kost'ou viac ako 7 palcov, teda do tabletov, 476 používatel'ov. 


\section{Aplikácia Geometrické tvary}

Aplikácia Geometrické tvary bola, rovnako ako aplikácia Zlomky, naprogramovaná v nástroji Android Studio. Aplikácia je trojjazyčná - podla zvoleného jazyka v telefóne sa zobrazí anglický text vždy, ked' jazyk telefónu nie je čeština alebo slovenčina.

Po spustení aplikácie sa zobrazí úvodné menu $\mathrm{s}$ možnostou výberu precvičovaniazákladných rovinných útvarov a základných priestorových telies. V časti základné rovinné útvary je možnost' precvičovat' obvody a obsahy útvarov štvorec, obdížnik, kosoštvorec, rovnobežník, lichobežník, trojuholník, pravidelný mnohouholník a kruh. Základné priestorové telesá umožňujú pracovat's útvarmi kocka, kváder, kolmý ihlan, zrezaný ihlan, rotačný kužel', zrezaný rotačný kužel' a gul'a.

Aplikácia Geometrické tvary bola zverejnená v obchode Google Play dňa 8.12.2015. Od tohto dátumu aplikáciu stiahlo 2120 jedinečných používatelov. Aktívne ju má nainštalovanú $\mathrm{v}$ jednom, alebo vo viacerých mobilných zariadeniach, 396 používatel’ov (aplikáciu majú nainštalovanú a zariadenie bolo online za posledných 30 dní). V predchádzajúcej kapitole sme spomínali, že nevieme presne určit, na kol'kých zariadeniach bola, alebo je, aplikácia nainštalovaná. S istotou vieme, že ju má nainštalovaných 396 používatel'ov.

Aplikáciu st’ahovali používatelia z rôznych častí sveta. Najviac používatel'ov stiahlo aplikáciu z Českej republiky. Kompletný zoznam krajín, kde bola aplikácia nainštalovaná, je možné vidiet' na obrázku 6. Používatelia, ktorí si stiahli túto aplikáciu do svojho mobilného zariadenia, používali väššinou mobilný telefón. Do tabletov si ju stiahlo 397 jedinečných použivatel’ov.

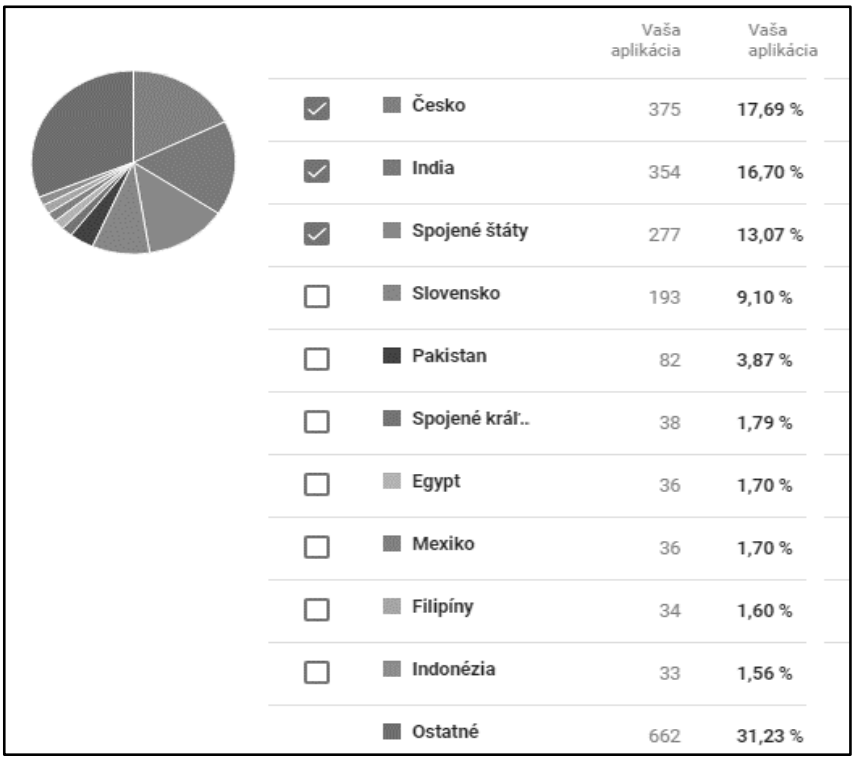

Obr. č. 6: Štatistické údaje o počte stiahnutí - aplikácia Geometrické tvary (zdroj: vlastný). 


\section{Aplikácia Matematika}

Aplikáciu Matematika sme vytvorili v prostredí App Inventor. Hlavným ciel’om naprogramovania tejto aplikácie bolo vytvorit’ jednoduchú aplikáciu, v ktorej si žiaci môžu zopakovat' učivo z časti sčitovanie, odčitovanie, násobenie a delenie celých čísiel. Túto aplikáciu môžu okrem žiakov používat' aj rodičia pri kontrole domácich úloh svojich detí. Učitelia ju môžu využit' na zvýšenie motivácie pri výučbe danej témy. Ďalším ciel'om vytvorenia tejto aplikácie bolo vyskúšanie možnosti vytvárania aplikácií v nástroji App Inventor. Zdrojový kód aplikácie je možné stiahnut’ na stránke:

\section{http://ai2.appinventor.mit.edu/?locale $=$ en\#6740536296472576}

Aplikácia bola zverejnená v obchode Google Play dňa 31.1.2017. Jednotlivé krajiny s počtom stiahnutí aplikácie je možné vidiet' na obrázku 7. Zatial' aplikáciu stiahlo do jedného, alebo viacerých mobilných zariadení, 62 jedinečných používatel'ov. Aplikácia nedosiahla také vysoké počty stiahnutí, ako dosiahli aplikácie Zlomky a Geometrické tvary. Možnú príčinu vidíme $\mathrm{v}$ podpore iba jedného jazyka aplikácie - slovenčiny. Prostredie App Inventor nám neumožňuje použit' viacero jazykov v aplikácii, ako je to pri programovaní v nástroji Android Studio. Nie je teda prekvapujúce, že najviac používatel'ov stiahlo aplikáciu zo Slovenska. Z obrázku vyplýva, že aplikáciu stiahli aj používatelia z krajín, ktorí pravdepodobne neovládajú slovenský jazyk. Predpokladáme, že túto aplikáciu stiahli z dôvodu vyskúšania, nakol'ko zdrojový kód aplikácie je dostupný na stránke App Inventor, a ten je v angličtine.

Aplikáciu si nainštalovali dvanásti používatelia na mobilné zariadenia s obrazovkou väčšou ako sedem palcov. Zvyšní používatelia si ju stiahli do mobilných telefónov.

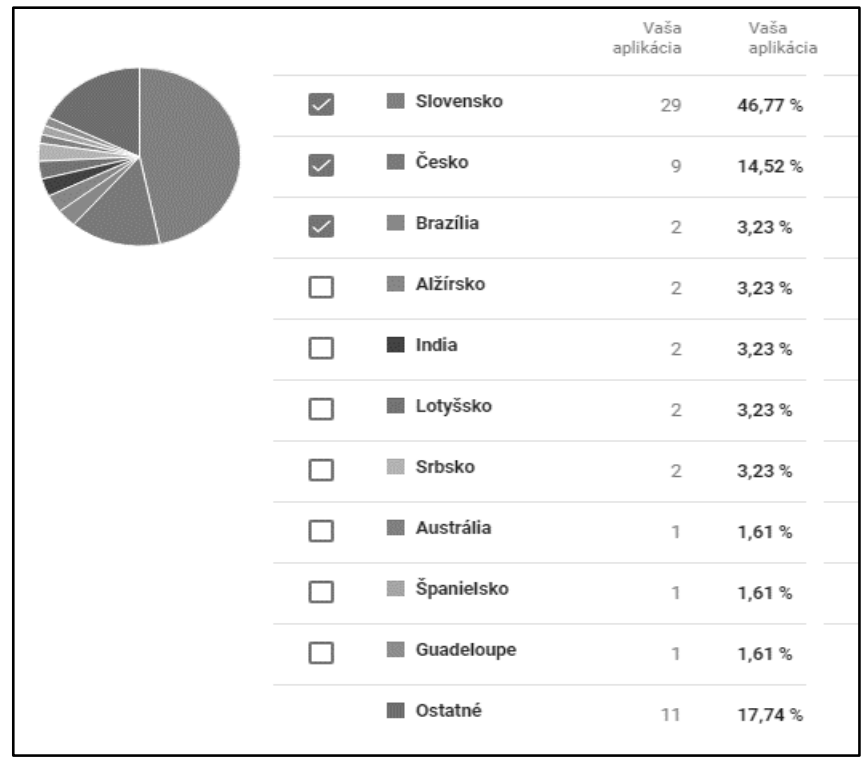

Obr. č. 7: Štatistické údaje o počte stiahnutí - aplikácia Matematika (zdroj: vlastný). 


\section{Aplikácia Rímske čísla}

Aplikácia Rímske čísla slúži na precvičovanie operácií prevodu arabských čísiel na rímske a naopak. Nakol'ko sme pri predchádzajúcej aplikácii Matematika zistili, že nástroj App Inventor obsahuje pomerne vel’a komponentov, je teda vhodný na vytváranie vzdelávacích aplikácií, rozhodli sme sa vytvorit’ aj aplikáciu Rímske čísla v tomto nástroji. Podobne, ako predchádzajúca aplikácia, aj táto podporuje iba jeden jazyk - slovenčinu. Zdrojový kód tejto aplikácie je možné stiahnut' na stránke:

\section{http://ai2.appinventor.mit.edu/?galleryId=5996067362177024}

Aplikácia Rímske čísla bola zverejnená v obchode Google Play dňa 13.11.2016. Do dnešného dňa stiahlo aplikáciu 218 jedinečných používatel'ov a 54 používatel'ov ju má momentálne nainštalovanú v mobilnom zariadení. Aplikáciu stiahlo najviac používatel'ov zo Slovenska. Kompletný zoznam krajín sa nachádza na obrázku 8.

$\mathrm{Na}$ rozdiel od predchádzajúcich aplikácií, štruktúra tejto aplikácie je podstatne jednoduchšia. Obsahuje iba jedno hlavné menu, v ktorom si používatel' môže vybrat' spoločného pomocníka, precvičovanie prevodov jednotiek z rímskych na arabské čísla a naopak, a zistenie výsledku. Vynechali sme teda menu, kde si používatel' vyberie najskôr, či chce precvičovat' prevody jednotiek z arabských na rímske čísla a rímske na arabské čísla (v tomto jednom menu si používatel' vyberie priamo operáciu, čo chce robit').

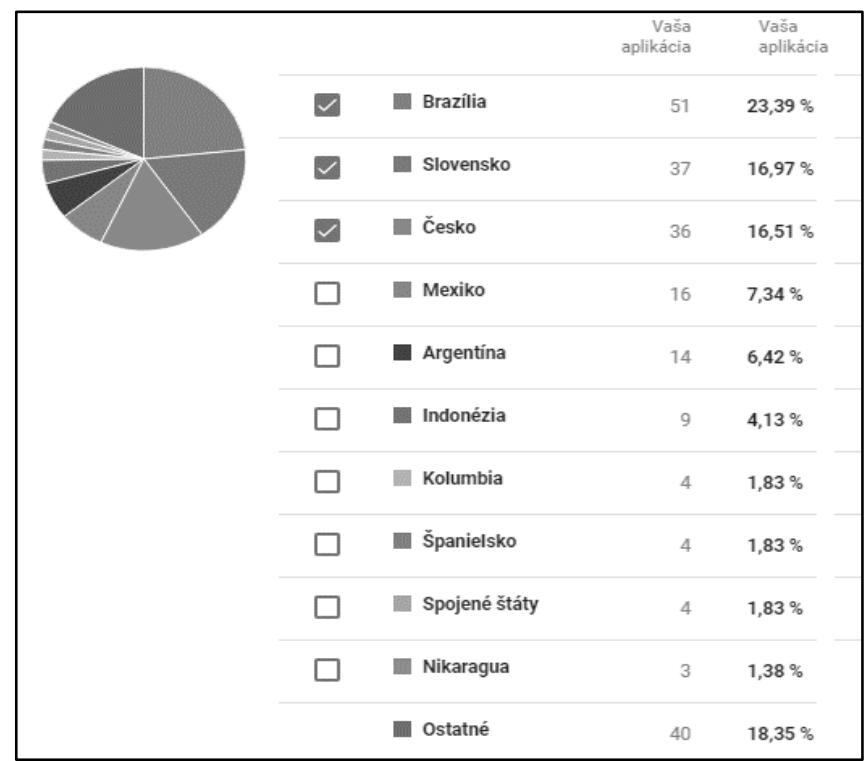

Obr. č. 8: Štatistické údaje o počte stiahnutí - aplikácia Rímske čísla (zdroj: vlastný). 


\section{Aplikácia Prevod jednotiek}

Vzdelávacia aplikácia Prevod jednotiek bola vytvorená obdobne, ako aplikácie Matematika a Rímske čísla, $\mathrm{v}$ nástroji App Inventor. Táto aplikácia je tiež jednojazyčná - texty sú iba v slovenčine. Používatelia môžu pomocou tejto aplikácie precvičovat' prevody jednotiek dížky, hmotnosti a plošného obsahu. Zdrojový kód aplikácie sa nachádza na oficiálnej stránke App Inventoru:

\section{http://ai2.appinventor.mit.edu/? galleryId=6032322129035264}

Aplikácia Prevod jednotiek bola zverejnená v obchode Google Play dňa 14.2.2017. Na obrázku 9 je možné vidiet’ jednotlivé krajiny, v ktorých si aplikáciu stiahlo spolu 269 jedinečných používatel'ov a z toho ju má stále nainštalovanú 75 použivatel’ov.

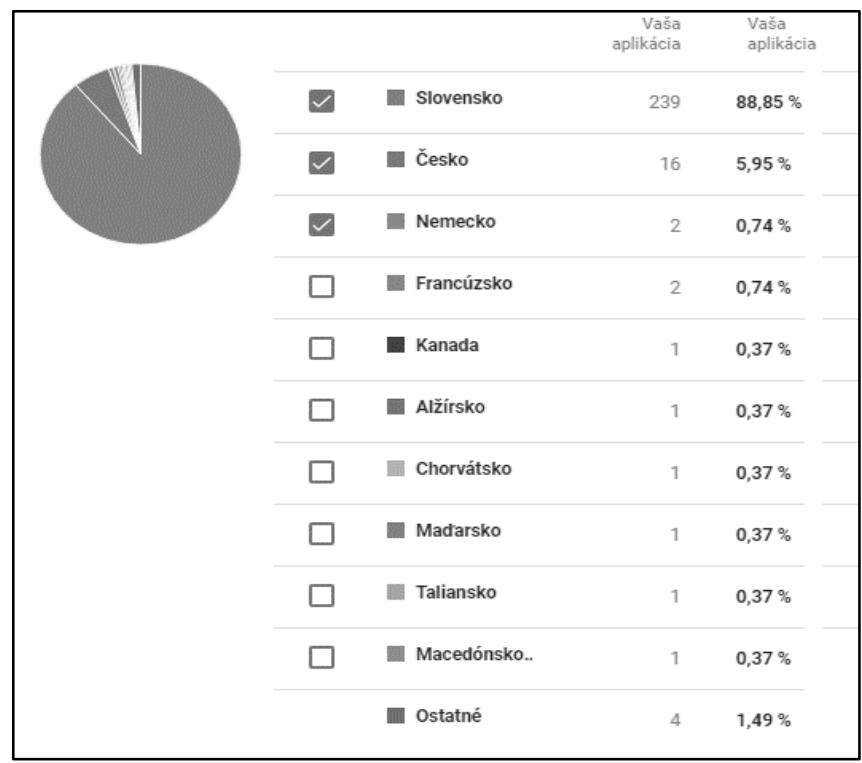

Obr. č. 9: Śtatistické údaje o počte stiahnutí - aplikácia Prevod jednotiek (zdroj: vlastný).

\section{Diskusia a záver}

Za posledných pár rokov sa na trhu rozšírili mobilné zariadenia, ako sú smartfóny a tablety. Tieto zariadenia otvorili nové možnosti vzdelávania. Hlavnými výhodami týchto zariadení je ich nízka obstarávacia cena a mobilita. Viaceré výskumy ukazujú, že používanie týchto zariadení je pre žiakov viac motivujúce ako tradičná forma výučby. Najväčší problém však vidíme $\mathrm{v}$ nedostatku materiálu, ktorý by sa dal využit' vo vyučovacom procese. Možné riešenie tohto problému ponúka nástroj App Inventor, ktorý umožňuje vytvárat' mobilné aplikácie bez predchádzajúcej znalosti programovania. $\mathrm{V}$ príspevku sme sa venovali tomuto nástroju podrobnejšie. Stručne sme vysvetlili postup vývoja mobilných aplikácií v tomto nástroji a opísali sme naše skúsenosti pri vyučovaní programovania pomocou tohto nástroja. Tento nástroj je vhodný pre vyučovanie 
programovania na základných školách, nakol'ko vychádza z detského programovacieho jazyka Scratch, ktorý sa momentálne používa na vyučovanie programovania na základných školách na Slovensku. V príspevku sme ukázali pät' vytvorených mobilných aplikácií určených ako podporný prostriedok vo vyučovacom procese. Autor príspevku vytvoril dve aplikácie $\mathrm{v}$ oficiálnom nástroji Android Studio a tri aplikácie vytvoril v už spomínanom nástroji App Inventor.

Každý zo spomínaných nástrojov má svoje výhody a nevýhody. Pri vytváraní aplikácií sme dospeli k názoru, že použitie nástroja Android Studio je vhodnejšie v prípade, že chceme vytvorit’ náročnejšiu aplikáciu, ktorá obsahuje viacero okien, náročnejšie operácie na výpočet a v prípade, ked' chceme aplikáciu, ktorá podporuje viacero jazykov. Tento nástroj však vyžaduje programátorské skúsenosti a je časovo náročnejší na vytváranie aplikácií. Nástoj App Inventor je zase vhodnejšie použit v prípade, že máme menej času na vytváranie aplikácií, prípadne nemáme dostatočné skúsenosti s programovaním. Pri vytváraní aplikácií si nemusíme pamätat' všetky príkazy, nakol'ko sa všetky nachádzajú na jednom mieste. Tento nástroj je vhodnejší pre začiatočníkov v programovaní, nakol'ko nám neumožňuje robit' časté programátorské chyby, ako napríklad vložit' číselnú hodnotu do príkazu, ktorý očakáva napr. textový ret’azec. Vel'kou výhodou nástroja App Inventor je možnost' vytvárat' aplikácie hocikde, kde máme $\mathrm{k}$ dispozícií počítač, mobil alebo tablet, ktorý je pripojený na internet.

Niektoré aplikácie sme overovali v praxi - na základnej škole v Banskej Bystrici, ale nakol'ko kvalitný výskum vyžaduje väčší počet takýchto aplikácií, tak sme sa rozhodli najskôr vytvorit' väčśi počet matematických aplikácií a následne ich podrobit' rozsiahlejšiemu výskumu. Z overovania aplikácií v praxi nám vyplynulo, že nami vytvorené aplikácie sú vhodné nielen pre žiakov, ale hlavne pre rodičov, ktorí nemusia vymýšlaat svojim det'om úlohy a následne ich počítat', stačí použit' niektorú $\mathrm{z}$ našich aplikácií. V súčasnosti pripravujeme viacero mobilných vzdelávacích aplikácií určených nielen pre matematiku. Rozpracované máme aplikácie pre úlohy na pytagorovu vetu a aplikáciu na matematické slovné úlohy. Po vytvorení spomínaných aplikácií plánujeme realizovat' výskum vhodnosti daných aplikácií na základných školách. Momentálne je tiež podaná žiadost' na grant pre vytvorenie mobilnej aplikácie na výučbu slovenčiny určenú hlavne pre zahraničných Slovákov, kde by autor príspevku vytváral mobilnú aplikáciu pre operačný systém Android. Z predmetu informatika momentálne analyzujeme možnosti vytvorenia vhodných aplikácií pre výučbu informatiky.

Príspevok bol spracovaný ako súčast' projektu KEGA č. 003TTU-4/2015 „Elektronické kurzy pre vyučovanie matematiky na základných školách a v prvých 4 ročníkoch osemročných gymnázii".

\section{Literatúra}

Bayerl, E., Mojšová, K. \& Voštinár, P. (2015). Mobil na hodine matematiky, výhoda alebo prekážka? In Dva dny s didaktikou matematiky. Praha: Univerzita Karlova v Praze. pp. 81-84.

Bayerl, E. \& Žilková, K. (2017). The impact of iBooks on Geometric conceptions of students about isometries. 2017. In 16th Conference on Applied Mathematics Aplimat 2017. Bratislava: Slovak University o Technology in Bratislava. pp. 56-65. 
Drigas, S. \& Pappas, A. (2015). A review of Mobile Learning Applications for Mathematics. In International Journal of Interactive Mobile Technologies (iJIM) 9. Wien : International Association of Online Engineering. pp. 18-23.

Koreňová, L. (2015). Digitálne technológie v školskej matematike. Bratislava: KEC FMFI UK Bratislava. $112 \mathrm{~s}$.

Lovászová, G. a kol. (2016). Mobilné technológie vo vyučovaní informatiky. Nitra: Univerzita Konštantína Filozofa v Nitre. 90 s.

Michaličková, V. (2016). Programovanie mobilných aplikácií v prostredí MIT APP INVENTOR 2. Nitra: Univerzita Konštantína Filozofa v Nitre. $93 \mathrm{~s}$.

Nocar, D. \& Zdráhal. T. (2015). The Potential of Dynamic Geometry for Inquiry Based Education. EDULEARN15 Proceedings. Valencia : IATED Academy. pp. 4992-4998.

Pokorný, M. (2013). Interactive Elements Can Increase the Efficiency of e-learning Course. In Information, Communication and Education Application, Advances in Education Research. Vol. 30. pp. 173-178.

Spitzer, M. (2014). Digitálni demence: jak pripravujeme sami sebe a naše deti o rozum. Brno: Host. 342 s.

Wolber, D., Abelson, H., Spertus, E. \& Looney, L. (2014). App Inventor 2: Create Your Own Android Apps. Sebastopol : O'Reilly Media. 360 p.

Warschauer, M. (2016). Laptops and literacy: Learning in the wireless classroom. New York, NY : Teachers College Press. 178 p. 